\title{
Enhancing Undergraduate Student Self-Efficacy and Learning with a Community Service Learning (CSL) Nutrition Workshop Assignment
}

\author{
Giulia Coletta, Rakhshan Kamran, Ayesha Khan, Kim Dej, \\ Janet M Pritchard
}

Community service learning (CSL) activities in undergraduate programs are associated with improvements in self-efficacy (confidence related to performing a specific task) and academic achievement. This study aimed to understand the impact of a CSL assignment on self-efficacy related to teaching community members about evidence-based nutrition and on the overall learning experience. Students were invited to participate in this mixed-methods study (surveys and focus groups), and the results indicate that the CSL activity not only increased students' self-efficacy related to nutrition science communication, but also gave students a greater feeling of connection to their community and an opportunity to practice skills needed for future careers.

Les activités d'apprentissage par l'engagement communautaire dans les programmes de premier cycle sont liées à une amélioration de l'autoefficacité (la confiance en sa propre capacité d'accomplir une tâche particulière) et du rendement universitaire. La présente étude vise à comprendre l'incidence d'un devoir d'apprentissage par l'engagement communautaire sur l'expérience d'apprentissage dans son ensemble et sur l'autoefficacité au sujet de la nutrition s'appuyant sur des données probantes - par rapport aux membres du corps enseignant. Les étudiants étaient invités à participer à une étude employant des méthodes mixtes (des sondages et des groupes de discussion). Les résultats indiquent que les activités d'apprentissage par l'engagement communautaire augmentent l'autoefficacité en matière de communication de la science de la nutrition. Qui plus est, ces activités donnent aux étudiants un sentiment accru d'appartenance à leur communauté ainsi qu'une occasion de mettre en pratique les compétences requises dans leur future carrière.

S elf-efficacy, or confidence related to completing a specific task, is defined as the personal judgement of ability to organize and execute actions to meet a goal (Bandura, 1977). Selfefficacy is multifactorial, and can be influenced by four sources: mastery experiences, vicarious (observational) experiences, social persuasions and physiological and psychological states (Bandura, 1997). In addition to self-efficacy being a key construct in the social cognitive theory (Bandura, 2004), self-efficacy influences motivation and cognition (Zimmerman, 2000) and is related to academic achievement (Wood \& Locke, 1987) and engagement in the classroom (Linnenbrink \& Pintrick, 2003). Students who have higher selfefficacy for performance tasks are more likely to undertake difficult tasks in the future, are better able to persevere in challenging situations and tend to achieve higher grades, specifically in science disciplines (Zimmerman, 2000; Anderson, Winett, \& Wojcik 2007). For these reasons, incorporating tasks into courses that can enhance students' self-efficacy may be ideal for creating a more meaningful, authenic learning experience, and may help prepare students for post-graduate opportunities and future careers, 
particularly in healthcare (Parle, Maguire, \& Heaven, 1997).

Community service learning (CSL) is an educational methodology that combines service in the community with purposeful learning activities (Canadian Alliance for Community Service Learning, 2018). CSL is a newer concept in the Canadian university setting, but service learning is a term that has been used for decades. Service learning is described as course-based experiences where students participate in an organized service activity, which meets community needs, and involves student reflection to gain understanding of course content and enhanced sense of civic responsibility (Bringle \& Hatcher, 1995). Service learning has been shown to have a positive impact on undergraduate students' self-efficacy, as these activities typically involve teaching, research and service in, for, or with the local community (Baetz et al., 2012). Service learning positively impacts self-efficacy for community service, academic performance, values, and leadership skills (Astin, Vogelgesang, Ikeda, \& Yee, 2000). Students who participate in CSL activities also demonstrate higher citizenship values and perceptions of social justice (Eyler, Giles, \& Brazton, 1997), which may be important attributes for students seeking careers in healthcare; a popular career path for many science students. The aim of this study was to investigate the impact of a CSL, course-based activity on undergraduate science students' self-efficacy for teaching community members about evidence-based nutrition practices, and to understand the impact of this activity on other aspects of the students' learning experience.

\section{Methods}

\section{Study Design}

This study was embedded in a Level 4 advanced nutrition undergraduate course. Over the course of one semester in the fall of 2017 , students designed and delivered a nutrition workshop to a community group of older adults, which was the CSL activity. The students worked in groups of four to develop a 45-minute interactive workshop on nutrition as it relates to the prevention and management of one of the following diseases: sarcopenia, osteoporosis, osteoarthritis, Alzheimer's disease, type 2 diabetes, or cardiovascular disease. Students were given time in class to work on their workshops. Students were also instructed to use the peer-reviewed scientific literature and other quality nutrition resources such as Health Canada and Dietitians of Canada, to form the content of their workshops. Feedback on workshop content, learning objectives and activities was provided by the professor and teaching assistant throughout the course. The assignment was worth $40 \%$ of the students' final grade, and consisted of:

1. Workshop guide: facilitator pre-reading, outline of learning objectives, activelearning activities, open-ended questions for each activity, resources and materials (35\%);

2. Rehearsal of workshop in class for professor, teaching assistant and peer feedback (15\%);

3. Community workshop execution (35\%);

4. Video and photo reflection $(10 \%)$; and

5. Peer evaluation $(5 \%)$.

After the assignment was introduced to students and groups were formed (week 2), a research assistant invited students to participate in the study when the Professor and teaching assistant were not present (week 3). This study was approved by the institution's Research Ethics Board, conforming to standards of ethical conduct in research involving human participants.

\section{Participants}

Participants were Level 4 Life Sciences students who were enrolled in a 12-week Advanced Nutrition course. The study included a convenience sample, as the number of student participants was restricted due to a course enrollment maximum. Students were 
informed that their lack of agreement to participate in the study would not have an impact on their course mark. Data was collected between October 2017 and January 2018 by a research assistant, who was not enrolled in the course. At the end of the semester (December 2017), the research assistant recruited participants for the focus group. Participants signed consent and confidentiality forms and agreed to an audio recording of the group interview.

\section{Outcome Measures}

A mixed-methods study was conducted using surveys and semi-structured focus group interviews to seek an understanding of the impact of the CSL activity on students' self-efficacy and learning experience.

\section{Quantitative Measures}

Pre- and post-surveys were administered to assess students self-efficacy related to various workshop tasks. The pre-survey was administered during week 4 (before students completed the workshop rehearsal and community workshop), and the post-survey was administered during week 12 (after all students completed the entire assignment). The pre- and postsurveys included the same questions. Students were asked to rank their level of self-efficacy (confidence) on a 10-point Likert scale ( $1=$ not very confident to $10=$ very confident) related to various workshop activities (Table 2).

\section{Qualitative Measures}

Students were invited to participte in the focus group to discuss their perceptions about the impact of the workshop CSL experience on their learning. Focus groups were conducted in December 2017 and January 2018, were 60 minutes in duration, and were led by a research assistant who moderated the discussion. A focus group guide, consisting of openended questions, was prepared a priori at the beginning of the study and used to facilitate the focus groups. However, opinions and thoughts raised by the participants that were not in the focus group guide were also pursued (Gill, Stewart, Treasure, \& Chadwick, 2008). The participants were encouraged to bring forward any relevant information, while the moderator ensured that all questions were adequately discussed. The focus group questions were:

1. What did this opportunity add to or take away from your learning experience?

2. How did this experience influence your impression of behaviour change and communicating nutrition-related information to the public?

3. How did this experience influence your personal growth?

4. How did this experience impact your selfefficacy for disseminating nutrition and health-related information to the public?

5. How do you feel this opportunity contributed to your future career plan?

6. What impact do you think the community engagement workshops had on community members?

The focus group audio recordings were transcribed using a thematic-framework analysis to identify key themes arising from the responses to the open-ended questions (Attride, 2001). Two research assistants independently reviewed and coded the transcripts to identified key themes using deductive and inductive reasoning. NVivo software was used to verify the key themes that emerged from the focus groups (Version 11, QRS International, Burlington, MA, USA).

\section{Additional Data Collection}

For descriptive purposes, year of birth, gender and past enrollment in another course with a communityoriented project was collected by the research assistant. The topic and the location of each workshop were also recorded. 


\section{Data Analysis}

The mean (SD) and frequency (percent) were computed for continuous and categorical data, framework analysis was used for the responses to the open-ended questions (Attride, 2001). Quantitative analyses were performed with SPSS Version 25.0 (IBM Corporation, Chicago, IL). Pvalue $\leq 0.05$ was considered significant.

\section{Results}

A total of $34 / 36(94 \%)$ students agreed to participate in the study and completed both pre and post-surveys. Table 1 presents the descriptive characteristics of the participants. All nine respectively. The student's t-test was used to explore the difference between mean self-efficacy scores from the pre- and post-surveys. A thematic-

workshops occurred during November 2017 and were conducted at various sites in Hamilton, Ontario, Canada. On average, self-effiacy increased by an average of 1.4 points from the pre- to postsurvey. There were significant improvements in self-efficacy for all questions related to the workshop tasks (Table 2). Out of the 34 students who participated, seven students had previously completed a course with a community-oriented project. A separate analysis of survey scores for these participants revealed that post-survey selfefficacy ratings were not significantly different from pre-survey scores for all 6 questions $(\mathrm{p}>0.05)$ (data not shown).

Table 1. Descriptive characteristics of study participants $(N=34)$

\begin{tabular}{|l|l|}
\hline - Age, years, mean (SD) & $23(1)$ \\
- & $28(82)$ \\
- Pemale & $7(21)$ \\
\hline Workshop location: & $1(11)$ \\
- Sackville Hill Senior's Centre & $3(33)$ \\
- Physical Activity Centre of Excellence (PACE) & $1(11)$ \\
- Ancaster Senior Achievement Centre (ASAC) & $4(44)$ \\
- Hamilton City Housing Residence & \\
\hline Workshop topics: & $1(22)$ \\
- Sarcopenia & $1(11)$ \\
- Osteoporosis & $1(11)$ \\
- Alzheoarthritis & $1(11)$ \\
- Hypertension & $2(22)$ \\
- Type 2 diabetes & $1(11)$ \\
\hline Cholesterol & \\
\hline Note: values are n (\%) unless otherwise indicated. & \\
\hline
\end{tabular}


Table 2. Pre- and post-survey ratings of self-efficacy

\begin{tabular}{|l|l|l|l|}
\hline Survey questions & \multicolumn{2}{l|}{ Self-efficacy rating } & \multirow{2}{*}{ P-value } \\
\cline { 3 - 3 } & Pre-survey & Post-survey & \\
\hline $\begin{array}{l}\text { I can effectively explain evidence-based nutrition information to a } \\
\text { lay population. }\end{array}$ & $6.2(1.9)$ & $7.7(2.3)$ & $0.007^{*}$ \\
\hline $\begin{array}{l}\text { I can explain the benefits and recommended guidelines for healthy } \\
\text { eating to a lay population. }\end{array}$ & $6.4(1.8)$ & $7.7(2.2)$ & $0.014^{*}$ \\
\hline $\begin{array}{l}\text { I can explain how healthy eating can help manage health } \\
\text { conditions prevalent in older adults. }\end{array}$ & $6.9(1.6)$ & $8.0(2.2)$ & $0.029^{*}$ \\
\hline $\begin{array}{l}\text { I can demonstrate strategies in eating healthy to a lay population. } \\
\text { I can help a lay person compose goals related to healthy eating. }\end{array}$ & $6.7(1.7)$ & $7.8(2.5)$ & $0.033^{*}$ \\
\hline $\begin{array}{l}\text { Overall, I can facilitate workshops related to evidence-based } \\
\text { nutrition and healthy eating to a lay population. }\end{array}$ & $6.2(2.2)$ & $8.1(2.1)$ & $0.039^{*}$ \\
\hline $\begin{array}{l}\text { Note: } * \text { denotes a significant difference between pre- and post- } \\
\text { survey mean }\end{array}$ & & & $<0.001^{*}$ \\
\hline
\end{tabular}

\section{Qualitative Results}

Two focus groups were conducted with three and four participants each during December 2017 and January 2018, respectively. Regarding the impact of the workshops on the students' learning experience, there were three themes that emerged from the focus groups:
1. Self-efficacy for science communication;

2. Enhancing the connection to the community;

3. Preparation for future careers.

These themes and select representative quotes are displayed in Table 3.

Table 3. Impact of community service learning experience on student learning: key themes

\begin{tabular}{|c|c|}
\hline Theme & Example quotations \\
\hline \multicolumn{2}{|l|}{ Theme \#1: Self-efficacy for science communication } \\
\hline $\begin{array}{l}\text { Improved communication to lay population and } \\
\text { simplifying science }\end{array}$ & $\begin{array}{l}\text { "I think it helped me because I never thought of myself as } \\
\text { like, the source to teach other people, right? But doing the } \\
\text { workshop, doing all the work, and seeing how engaged } \\
\text { they were and they were looking to you for the knowledge } \\
\text { and were interested in asking the questions, it kind of did } \\
\text { make me feel a little bit better about my ability to do it, } \\
\text { and teach, and be a reputable source to them." }\end{array}$ \\
\hline
\end{tabular}


Communication forced enhanced learning

Public speaking decreased anxiety because of increased engagement and team work
"It's kind of like you have to know the content, you have to be able to answer the questions, it kind of made me learn it more, and remember it better."

"In the actual workshop when people are giving you eye contact and really taking notes and really asking you questions that you're talking about, you're like 'wow I'm actually impacting their lives and they're really taking in the information that I'm saying and that I worked hard on research', and yes it helps with your confidence because people are actually listening."

Theme \#2: Enhancing connection to the community

Feeling of purpose

Fostered action-oriented conversations

Decision to pursue careers in healthcare and higher education

Development of soft skills

\section{Theme \#3: Preparation for future careers}

"I found that this workshop was interesting in the fact that we got to interact with the community, it was kind of nice to be able to take what we were learning and what we were studying and actually apply it and like be able to kind of give back to the community and just see what our knowledge can mean."

"I think the rationale for that was just because what we were thinking was there are parts of the Hamilton community that are disadvantaged socioeconomically and those might be the ones that need the most education."

\section{Discussion}

This study demonstrated that a CSL activity, such as developing and delivering a nutrition workshop in the community, had a positive impact on students' self-efficacy and enhanced the learning experience
"It solidified the fact that I want to work with people and share health knowledge."

"I think it is more beneficial than your standard presentation, because you have to know the information better, and it improves your skills and all that, improves group work, all the things that have already been said, and also, you can put it on a resume, it is not just for marks, it's more - just more, you're getting more out of it."

for students by improving science communication skills, creating a connection to community and preparing students for future careers. Overall, students felt more confident in their ability to effectively communicate evidence-based nutrition information to a lay population after completing this workshop assignment. Some students in our sample 
had participated in community-oriented projects in previous courses, and there was no significant impact of completing the current assignment on their levels of self-efficacy related to various workshop tasks. This indicates that for students who have had experience with CSL-type assignments, the assignment objectives, specific activities in the assignment, or target audience may need to be modified in order to make the assignment more novel and to elicit an impact in more advanced students. On the other hand, our study was not equipped to adequately explore this question in the small subset of participants who had prior CSL experience, and thus more quantitative and qualitative research is needed to clarify the relationship.

CSL activities are an important aspect of a student's undergraduate experience. They encourage communication of academic knowledge, translation of knowledge to a lay population resulting in social responsibility, and enhance personal and interpersonal development (Eyler, Giles, Stenson, \& Gray, 2001). Similar to a large study of over 22,000 undergraduate students (Astin, Vogelgesang, Ikeda \& Yee, 2000) and another meta-analysis involving over 11,000 students (Celio, Durlak \& Dymnicki, 2011), our study showed that a CSL assignment significantly improved students' self-efficacy related to various workshop tasks. Self-efficacy is an important outcome in education because students with high self-efficacy are more likely to have better problem solving skills (Larson, Piersel, Imao, \& Allen, 1990), persist in math and science academic disciplines, are more likely to graduate from a program (Larson et al., 2015), pursue math and science-related careers (Luzzo, Hasper, Albert, Bibby \& Martinelli, 1999), and have better academic performance (Museus \& Hendel, 2005). As self-efficacy can be influenced by four main factors-mastery experiences, vicarious experiences, social persuasions, and physiological and psychological states (Bandura, 1997) —it is likely that the in-class workshop rehearsal played a role in improving students' self-efficacy. During the rehearsal, students had the opportunity to practice their workshops in front of peers and receive positive and constructive feedback on workshop content, activities and body language. As students had the opportunity to observe their peers practicing, this may have enhanced self-efficacy through vicarious experiences. The positive feedback that students received from the professor, teaching assistant, peers and group members may have contributed to social persuasion and positive reinforcement. In addition, by having the opportunity to practice the workshop, students may have benefited from mastery experience. This may have also reduced the feelings of anxiety when public speaking, improving the students' physiological and psychological states. Other studies have demonstrated that self-efficacy can be influenced by interventions or programs in the academic environment. For example, in a four week study, Luzzo, Hasper, Albert, Bibby \& Martinelli (1999) showed that an intervention focused on vicarious and mastery experiences improved selfefficacy among undergraduate students compared to a control group who were not exposed to vicarious and mastery experiences. In another study, Wheeler \& Wishusen (2014) showed that self-efficacy rating scores were higher for students who participated in a Biology Boot Camp with peer-to-peer interactions and learning communities (vicarious experiences), detailed feedback sessions (social persuasion) and review sessions (mastery experience). These findings support the notion that an improvement in selfefficacy in our study may be beneficial to the student, and may lead to more students pursuing careers in science, however, this should be explored in a longerterm study. In addition, it would be interesting to learn which aspect of the CSL assignment contributed most to self-efficacy improvement.

The focus group discussions revealved three key themes: self-efficacy for science communication, connection to the community and direction for future careers. Undergraduate students in science disciplines typically have few in-course opportunities to practice translating scientific information to a lay population, which is an essential skill for healthcare professionals (Woods, Pasold, Boateng, \& Hense, 
2014). This assignment gave students the opportunity to practice science simplification and communication skills, which in turn forced enhanced learning, as students were responsible for understanding the content in order to communicate it in lay terms (Tucker \& McCarthy, 2001). Students reported an increase in engagement and teamwork skills, and a decrease in public speaking anxiety, which aligns with the improvement in communication skills with a CSL activity (Tucker \& McCarthy, 2001). Students also reported a greater sense of purpose, as they were able to give back to the community and transfer their knowledge about nutrition for the management and prevention of chronic disease. Engagement and positive interactions builds authentic partnerships between the students and the community members, resulting in a desire to continue to share knowledge to facilitate action-oriented conversations (Cashman \& Seifer, 2008). Action-oriented conversations are partnerships between the community and campus partners to provide services to communities in need (McMaster University, 2016). This project provided a stronger sense of community for students, which is important for fostering community-campus connections and future community engagement work (Eyler et al., 2001). Lastly, this CSL activity contributed to preparation for future careers. Students found that this experience solidified their decisions to pursue careers in healthcare and provided opportunities to develop soft skills, such as organization and teamwork. Given the positive impact on self-efficacy, it is not surprising that students gained understanding and clarity around career goals, as Lent and colleagues proposed that the Social Cognitive Career Theory links self-efficacy to the pursuit of programs and careers in the science, technology, engineering and mathematics (STEM) fields (Lent, Brown \& Hackett, 1994). This is a benefit to students, but also to the community, as exposing undergraduate students to public health through this CSL activity may help to ensure that students are able to contribute to developing healthy communities (Cashman \& Seifer, 2008).
The limitations of our study should be considered. The population studied was a small cohort of a larger Life Science program. The generalizability of this CSL assignment to larger classes and students enrolled in different levels remains to be determined. One of the challenges to scaling-up this assignment is that the sources of self-efficacy, such as mastery experience, vicarious experience and social persuasion, may be lost in a larger class. Another limitation is that we did not have the power to conduct a more detailed sub-group analysis investigating why students who previously participated in community-oriented courses did not experience a significant increase in self-efficacy. Furthermore, we were not able to investigate the specific details such as content, objectives, deliverables, and timeline of the previous community-oriented projects, which may be an important consideration. Finally, our study did not include a control group, which makes it challenging to compare the impact of this CSL assignment to another more traditional assignment in a small class.

\section{Conclusion}

CSL activities enhance the undergraduate student learning experience and can positively impact selfefficacy, community values, and preparation for future careers. This pedagogical approach may be ideal for undergraduate science students aspiring to work in healthcare in the future, as this experience allowed students to practice teaching the lay public about nutrition and health and fostered a sense of responsibility towards helping others in the community.

\section{References}

Anderson, E. S., Winett, R. A., \& Wojcik, J. R. (2007). Self-regulation, self-efficacy, outcome expectations, and social support: social cognitive theory and nutrition behavior. Ann 
Behav Med, 34(3), 304-312. Doi:10.1080/08836610701677659

Astin, A. W., Vogelgesang, L. J., Ikeda, E. K., \& Yee, J. A. (2000). How service learning affects students. Higher Education, 144. Retrieved from http://digitalcommons.unomaha.edu/slcehig heredhttp://digitalcommons.unomaha.edu/s lcehighered/144

Attride-Stirling, J. (2001). Thematic networks: an analytic tool for qualitative research. Qualitative research, 1(3), 385-405. Doi 10.1177/146879410100100307

Baetz, B., Doubleday, N., Eby, J., Hicks, A., Hupfer, M., Saeed, H., ... Whalen, K. (2012). Forward with Integrity: Community Engagement Task Force Position Paper. Retrieved from https://president.mcmaster.ca/wpcontent/uploads/2016/04/PP_CE_final.pdf

Bandura, A. (1977). Self-efficacy: Toward a unifying theory of behavioral change. Psychological Review, 84(2), 191-215. doi: 10.1037/0033295X.84.2.191

Bandura, A. (2004). Health promotion by social cognitive means. Health Education Behaviour, 31(2), 143-164.

Doi:10.1177/1090198104263660

Bringle, R. G., \& Hatcher J. A. (1995). A community service learning curriculum for faculty. Michigan Journal of Community Service Learning, 2(1), 112-122. Retrieved from https://scholarworks.iupui.edu/handle/1805 $/ 4591$

Canadian Alliance for Community Service Learning. (2018). What is community service learning? Retrieved from http://communityservicelearning.ca/what-is$\mathrm{csl} /$ what-is-community-service-learning/

Cashman, S. B., \& Seifer, S. D. (2008). Community service learning: an integral part of undergraduate public health. American Journal of Preventive Medicine, 35(3), 273-278. Doi: 10.1016/j.amepre.2008.06.012

Celio, C.I., Durlak, J., \& Dymnicki, A. (2011) A Meta-analysis of the Impact of Community service learning on Students. Journal of
Experiential Eduation, 34(2), 164-181. Doi:10.1177/105382591103400205

Eyler, J., Giles, D. E., \& Braxton, J. (1997). The Impact of Community service learning on College Students. Michigan Journal of Community Service Learning, 4(1), 5-15. Retrieved from https://quod.lib.umich.edu/m/mjcsl/32395 21.0004.101/1/--impact-of-community service learning-on-collegestudents?g $=$ mjcslg;page $=$ root;size $=100 ;$ view $=$ image $; \mathrm{xc}=1$

Eyler, J., Giles Jr, D. E., Stenson, C. M., \& Gray, C. J. (2001). At a glance: What we know about the effects of community service learning on college students, faculty, institutions and communities, 1993-2000: Third Edition. Higher Education, Retrieved from https://digitalcommons.unomaha.edu/cgi/vi ewcontent.cgi?referer=https:// scholar.google .ca $/$ \&httpsredir $=1 \&$ article $=1137 \&$ context $=$ sl cehighered

Gill, P., Stewart, K., Treasure, E., \& Chadwick, B. (2008). Methods of data collection in qualitative research: interviews and focus groups. British Dental Journal, 204(6), 291-295. Doi:10.1038/bdj.2008.192

Larson, L. M., Piersel, W. C, Imao, A. K., \& Allen, S. J. (1990). Significant predictors of problemsolving appraisal. Joumal of Counseling Psychology, 37, 482-490. Retrieved from http://psycnet.apa.org/buy/1991-07264-001

Larson, L.M., Pesch, K.M., Surapaneni, S., Bonitz, V.S., Wu, T., \& Werbel, J.D. (2015). Predicting Graduation: The Role of Mathematics/Science Self-Efficacy. Journal of Career Assessment, 23(3), 399-409. Doi:10.1177/1069072714547322

Lent, R. W., Brown, S. D., \& Hackett, G. (1994). Toward a unifying social cognitive theory of career and academic interest, choice, and performance. Journal of Vocational Behavior, 45, 79-122. Doi:10.1006/jvbe.1994.1027

Linnenbrink, E. A., \& Pintrick, P. R. (2003). The role of self-efficacy beliefs in student engagement and learning in the classroom. Reading and 
Writing Quarterly, 19(2), 119-137. Doi:10.1080/10573560308223

Luzzo, D.A., Hasper, P., Albert, K.A., Bibby, M.A., \& Martinelli, E.A. (1999) Effects of SelfEfficacy-Enhancing Interventions on the Math/Science Self-Efficacy and Career Interests, Goals, and Actions of Career Undecided College Students. Journal of Counselling Psychology, 46(2), 233-243. Doi:10.1037/0022-0167.46.2.233

McMaster University. (2016). Pillars of Community Engagement. Retrieved from https://community.mcmaster.ca/docs/defau lt-source/default-document-library/ocepillars-of-ce-priorities_august2016.pdf?sfvrsn=e76ebeb0_0

Museus, S. \& Hendel, D. (2005). Test scores, selfefficacy and the educational plans of first-year college students. Higher Education Review. 6388.Retrieved from http://www.higheredinreview.org/articleindex/\#TOC-Volume-2-2005-

Parle, M., Maguire, P., \& Heaven, C. (1997). The development of a training model to improve health professionals' skills, self-efficacy and outcome expectancies when communicating with cancer patients. Social Science \& Medicine, 44(2), 231-240. Doi:10.1016/S02779536(96)00148-7

Tucker, M. L., \& McCarthy, A. M. (2001). Presentation self-efficacy: Increasing communication skills through community service learning. Journal of Managerial Issues, 13(2), 227-244. Retrieved from https://www.jstor.org/stable/40604346

Wheeler, E.R., \& Wischusen, S.M. (2014) Developing Self-regulation and Self-efficacy: A Cognitive Mechanism Behind the Success of Biology Boot Camps. Electronic Journal of Science Education. 18(1),1-16. Retrieved from http://ejse.southwestern.edu/article/view/1 2466
Wood, R. E., \& Locke, E. A. (1987). The relation of self-efficacy and grade goals to academic performance. Educational and Psychological Measurement, $\quad 47, \quad$ 1013-1024. Doi:10.1177/0013164487474017

Woods, J. L., Pasold, T. L., Boateng, B. A., \& Hense, D. J. (2014). Medical student self-efficacy, knowledge and communication in adolescent medicine. Int J Med Educ, 5, 165-172. Doi:10.5116/ijme.53d3.7b30

Zimmerman, B. J. (2000). Self-Efficacy: An Essential Motive to Learn. Contemp Educ Psychol, 25(1), 82-91. Doi:10.1006/ceps.1999.1016

\section{Biographies}

Giulia Coletta is a graduate from the Honours Life Sciences (B.Sc) Program at McMaster University. Giulia was a research assistant on the project, under the supervision of Dr. Pritchard.

Rakhshan Kamran is a graduate from the Honours Life Sciences (B.Sc) Program at McMaster University. Rakhshan was a research assistant on the project, under the supervision of Dr. Pritchard.

Dr. Ayesha Khan is an Assistant Professor in the School of Interdisciplinary Science and Psychology, Neuroscience and Behaviour at McMaster University. Dr. Khan is also the Associate Director (Curriculum and Pedagogy) in the School of Interdisciplinary Science.

Dr. Kim Dej is an Associate Professor in the School of Interdisciplinary Science and is the Associate ViceProvost, Faculty, at McMaster University.

Dr. Janet M. Pritchard is an Assistant Professor in the School of Interdisciplinary Science and Department of Kinesiology at McMaster University. 